Relations industrielles

Industrial Relations

\title{
Luc BOYER, Noël EQUILBEY : Le projet d'entreprise. Paris, Les Éditions d' Organisation, 1986, 135 pp., ISBN 2-7081-0749-6
}

\section{Paul Beaulieu}

Volume 42, numéro 4, 1987

URI : https://id.erudit.org/iderudit/050372ar

DOI : https://doi.org/10.7202/050372ar

Aller au sommaire du numéro

Éditeur(s)

Département des relations industrielles de l'Université Laval

ISSN

0034-379X (imprimé)

1703-8138 (numérique)

Découvrir la revue

Citer ce compte rendu

Beaulieu, P. (1987). Compte rendu de [Luc BOYER, Noël EQUILBEY : Le projet

d'entreprise. Paris, Les Éditions d'Organisation, 1986, 135 pp., ISBN

2-7081-0749-6]. Relations industrielles / Industrial Relations, 42(4), 881-883.

https://doi.org/10.7202/050372ar

Tous droits réservés @ C Département des relations industrielles de l'Universite Laval, 1987
Ce document est protégé par la loi sur le droit d'auteur. L’utilisation des services d'Érudit (y compris la reproduction) est assujettie à sa politique d'utilisation que vous pouvez consulter en ligne.

https://apropos.erudit.org/fr/usagers/politique-dutilisation/ 
of a lack of a sufficient community of interests in relation to permanent workers. They are not entitled to some of the benefits of employment standard legislation the application of which requires the accrual of a defined period of continuous employment (e.g., termination of employment notice, unemployment insurance benefits - see also the criticism of the Forget Commission). In many provinces the legislation does not establish a pro rating system which could at least provide them with some proportion of the benefits in question.

England examines the arguments justifying an inferior treatment of atypical workers relating to the principles of equality laid down not only in several philosophical and Christian ethic systems but also in the Canadian Charter of Rights and Freedoms and human rights legislation. The Charter does not provide «pure» equity because section I does envisage it protected rights being overriden on exceptional circumstances. The inferior legal treatment of atypical workers must pass now the relatively rigorous acid test of justification under section I of the Charter. England demonstrates in details that in most cases this justification will fail.

Due to the requirements of human rights and constitutional law but also to a matter of «fair» public policy, England submits several reforms to the present canadian labour law. These proposals are very close to the recommendations of the Wallace Report and the Equal Rights Commission particularly in regard to part time workers (e.g., equal wages for all performing work of equal value all fringe benefits available to all employees on a pro rated basis to account for reduced working hours). For other atypical workers, namely temporary workers supplied by an agency, the author pleads for the enactment of a specific legislation. Such a legislation only exists in British Columbia.

There, farm labor contractors are required to obtain an agency licence and to maintain a payroll list. The payment of wages is also subject to a specific regulation. If a client enters into an arrangement with a contractor whom he knows to be unlicensed, he is deemed to be the employer of the employees. Such type of legislation is well known in some European countries (e.g., France, Germany).

England's study does not only provide a concise view on the deteriorated social and economic situation of atypical workers but also demonstrates their disadvantages within present law and sets forth some proposals to resolve the inequalities. One should wish this book a broad and attentive audience especially on the legislator's side who could profit from these proposals.

Udo MAYER

University of Hamburg, RFA

Le projet d'entreprise, par Luc Boyer et Noël Equilbey, Paris, Les Editions d'organisation, 1986, 135 pp., ISBN 2-7081-0749-6

La rapidité avec laquelle s'effectuent les changements et les mutations au sein de l'environnement socio-économique des entreprises pose un défi constant aux cadres supérieurs des organisations. Ils ont à composer avec des cycles de changement de plus en plus courts dans le temps et à réorienter rapidement leurs entreprises vers de nouveaux choix stratégiques qui leurs seront davantage profitables.

Les notions liées à la planification stratégique des entreprises ont sensiblement évoluée au cours des cinq dernières années. La notion de stratégie d'entreprise est devenue plus transparente. D'une vision classique où l'entreprise est considérée en tant qu'organisme technico- 
économique, l'entreprise est maintenant perçue comme étant simultanément un agent de production, une organisation sociale et un système politique d'acteurs. Il en découle que l'environnement de l'entreprise passe d'une conception étroite centrée sur les marchés à une dimension plus globale intégrant les dynamiques internes et externes à l'entreprise. Par conséquent, l'effort stratégique de l'entreprise, qui pour les classiques du domaine se définit comme la façon dont l'entreprise alloue ses ressources dans le but de modifier l'équilibre concurrentiel à son avantage, s'en trouve modifiée. La stratégie, selon une approche rénovée, consistera donc à «créer les conditions de congruence (économiques, techniques, sociales et politiques) entre l'environnement et l'entreprise de sorte que celle-ci dispose d'un potentiel maximum de performances" (A.C. Martinet, Management stratégique: organisation et politique, Paris, McGrawHill, 1984, p. 33).

C'est là qu'intervient le concept de «projet d'entreprise». De nos jours, les entreprises sont rarement le fruit de l'action d'un leader charismatique intégrant l'ensemble du sommet hiérarchique, mais davantage le résultat d'une dynamique administrative menée collectivement. Le projet d'entreprise vient faciliter cette prise en charge collective de la réalisation de l'effort stratégique de l'entreprise. Il fait le pont entre la stratégie conçue et l'action située dans le temps et dans l'espace.

Le projet d'entreprise est constituée par la synthèse des grandes priorités économiques et sociales que l'entreprise se donne. Il indique les voies et les moyens qu'elle entend adopter pour parvenir à ce qu'elle a la volonté d'être (p. 16). Le projet est une vision du futur, une volonté de parvenir à cette fin, un système de valeurs partagées, des priorités et des axes majeurs pour l'action. Il est le fruit d'un large processus de communication et de mobilisation qui constitue «un pacte» de participation à la décision et dont la forme se traduit par un document écrit représentant le «message» que l'entreprise transmet aux différents segments de son environnement. L'entreprise se donne un discours collectif formalisé.

Au plan des intentions qui motivent le concept et la pratique du projet d'entreprise il y a la volonté de définir les conditions de la réussite. Il y a aussi le désir de voir les cadres acquérir des réflexes qui leur donneront une lecture commune de l'environnement afin qu'ils produisent des stratégies décentralisées cohérentes avec l'ensemble. Ainsi, l'entreprise veut intégrer sur une base hiérarchique les projets que nourrissent les acteurs à différents niveaux: individus, équipes, unités de production, entreprise globale. En ce sens, le projet d'entreprise est un processus d'intégration et d'unification de ses acteurs.

Le but du livre Le projet d'entreprisé est de proposer une démarche logique et rationnelle pour la prise en charge de l'élaboration et de l'implantation d'un projet d'entreprise. Il s'agit d'un ouvrage bien écrit, d'une lecture facile et abondamment illustrée de schéma et d'exemples tirés de la pratique. Les auteurs, tous deux consultants chez Hay-France, ont eu amplement l'occasion de mettre à l'épreuve le concept de projet d'entreprise dans des organisations de différents niveaux de compléxité.

L'ouvrage est structuré selon sept (7) chapitres. Le chapitre 1 définit le concept de projet d'entreprise. Le second traite de la nécessité primordiale d'effectuer un diagnostic sérieux de la culture de l'entreprise. Le chapitre suivant aborde la question des valeurs clefs et de leur rôle central dans la structuration du projet d'entreprise. Viennent ensuite trois chapitres sur les méthodologies d'élaboration et sur la dynamique de la mise en oeuvre du projet. Finalement, l'ouvrage se termine par une analyse du projet d'entreprise en tant qu'acte volontaire de communication. 
Ce livre traduit assez bien la préoccupation de renouveau de l'entreprise en France. Il est fondamentalement dédié au contexte et à la sensibilité managériale française. C'est un ouvrage que le lecteur a intérêt à mettre en résonnance avec celui de Reitter et Ramanantsoa, Pouvoir et politique (Paris, McGraw-Hill, 1985).

Paul BEAULIEU

Université du Québec à Montréal

Industrial Relations in a New Age, by Clark Kerr and Paul Staudonar, Editors, San Francisco, Calif., 1986, 419 pp., ISBN 0-55542-013-3

Clark Kerr and Paul Staudohar have edited a useful addition to the broad literature on industrial relations. According to the authors the «...Central theme of this book is the organization of work in industrial society, and its structure flows from individual to group actions and from the past to the future.» They claim that the volume offers a new approach to the study of industrial relations.

To accomplish their goals the authors selected 95 readings and divided them into thirteen chapters. A listing of the chapters gives an indication of the ambitious nature of Industrial Relations in a New Age: The Meaning of Work: The Changing Work Force; Job Satisfaction and Dissatisfaction; Improving Quality of Work Life; Increasing Worker Participation in Management; Industrial Relations Systems Worldwide; Public Policies Governing Industrial Relations in America; Collective Bargaining; Industrial Conflict and Its Resolution; Political Action by Unions and Workers; Comparing Industrial Relations Systems; Forces Shaping Industrial Societies; and the Future of Industrial Relations. Each chapter is preceded by a brief discussion of the selections and each chapter is followed by a series of discussion questions.

The scope of the topics covered is very reminiscent of an earlier classic text also co-edited by Kerr, Unions, Management and the Public. However, as Kerr and Staudohar point out, Industrial Relations in a New Age «...goes much beyond what is normally included under the scope of industrial relations.» They write that, «the structure and goals of work and the work force are changing, as is the government's involvement in industrial relations. These changes and their implications are the topics of this volume.»

Given such breadth it is almost inevitable that some topics which one would like to see in the book are not included. Nonetheless this reviewer is puzzled by the absence of a specific selection on concession bargaining given the impact this type of bargaining has had on North America industrial relations. Also, given the books' focus on changing relationships, it is puzzling not to find a section devoted to labour's role in corporate «bailouts». Surely the Chrysler recovery, which involved intense efforts by labour, management and government, would qualify as breaking ground for a «new age» in labour relations.

The book also unfortunately suffers from the all too common tendency of American authors to ignore the unique character of the Canadian industrial relations system. This is all the more disturbing in a volume co-edited by a distinguished comparative scholar such as Clark Kerr and in a volume in which two chapters are devoted to comparative issues. Innovative legislative developments in Canada such as first agreements arbitration and anti-strike breaking provisions certainly merit discussion. Similarly it would have been useful to examine labour's relationship to the NDP as a contrast to labour's relationship with political parties in the United States. 